\title{
REPORTING OBLIGATIONS OF COMPANIES LISTED ON NEWCONNECT - SCOPE, IRREGULARITIES IN COMPLETION AND THEIR CONSEQUENCES
}

\author{
Katarzyna Klimczak \\ Warsaw School of Economics, Poland
}

\begin{abstract}
The subject taken up in the article is the reporting obligations of companies trading their shares in the alternative trading system operated by the Warsaw Stock Exchange. The objective of the study, the results of which have been presented in this article, was the identification of the type of reporting obligations imposed by the Market Organiser on companies listed on NewConnect as well as the ascertainment of the most common irregularities in fulfilling these obligations and their regulatory consequences.

Companies listed on New Connect are required to prepare current and periodic reports, whereas the Alternative Trading System Rules specify in detail the minimum information that the relevant reports must contain as well as the manner and timescale of their publication. The conducted analyses demonstrated that reporting irregularities are the most common type of breaches of the Alternative Trading System Rules. The number of sanctions imposed on participants by the Market Organiser in connection with such breaches is steadily increasing since the market's beginning. The majority of these irregularities concern periodic reports.
\end{abstract}

Keywords: reporting obligations, irregularities, alternative trading system, NewConnect

JEL code: M400, G100

\section{Introduction}

NewConnect is one of the financial markets in the world which is based on an alternative trading system. The organiser and operator of the alternative trading system on NewConnect is the Warsaw Stock Exchange. First quotings on NewConnect were on 30 August 2007. At the end of 2014, 431 companies were listed on NewConnect. At present (as at the end of September 2016) NewConnect lists 407 companies, 9 of which are foreign companies (NewConnect Annual Market Statistics).

The basic differences between alternative trading systems and regulated markets are simplified admission procedures and more liberal reporting requirements. NewConnect was developed for small and medium enterprises with a large growth potential that need capital for their development. The main purpose of the Warsaw Stock Exchange launching NewConnect was giving small and medium enterprises that found it difficult to obtain the right level of funding the chance to grow.

The reporting practices of companies listed on NewConnect were the subject of some previous studies (Dyczkowska, 2015; Białek-Jaworska and Drązikowska, 2015; Klimczak, 2015; Zawadzki, 2014).

This article considers the reporting obligations of companies listed on NewConnect. The objective of the study, the results of which have been presented in this article, was the identification of the most important reporting obligations imposed by the Alternative System Organiser and ascertainment of the most commonly occurring irregularities in fulfilling these obligations and their regulatory consequences. The conducted analysis encompassed the reporting obligations of companies listed on this market but did not cover the extent and rules 
of information documents prepared by companies requesting admission to trading in an alternative system.

\section{Reporting obligations of NewConnect listed companies}

In the first part of the study, an analysis of the rules and regulations applicable in the alternative trading system on NewConnect was conducted in order to define the scope of the information that must be provided by companies listed there.

The basic rules connected with the organisation of an alternative trading system have been set out in the Alternative Trading System Rules adopted by the Warsaw Stock Exchange Management Board.

According to the Alternative Trading System Rules (Current and Periodical Information in the Alternative Trading System on the NewConnect Market, 2016), issuers are required to submit two types of reports: current and periodic.

The current report must be submitted promptly after the occurrence of the event or circumstances that they are required to report.

Issuers are required to provide the following information in the form of a current report:

- Changes to the amount or structure of the issuer's share capital registered by court,

- Acquisition of shares in registered conditional capital,

- Decision adopted by the issuer's management board concerning an increase of the issuer's share capital within the authorised share capital,

- Change of rights attached to the issuer's financial instruments,

- Redemption of the issuer's financial instruments,

- Appointment, dismissal or resignation of a managing or supervisory person,

- Issue of bonds or subscription warrants,

- Conclusion of an agreement concerning performance of the tasks of Authorised Adviser,

- Conclusion of an agreement on financial statement audit,

- Fine or other disciplinary measures imposed on the issuer by the Alternative System Organiser or other supervision authority,

- Submission of the application with the competitive supervision authority for approval of the relevant public information document.

Apart from these general rules concerning current reports, the Alternative Trading System Rules (Current and Periodical Information in the Alternative Trading System on the NewConnect Market, 2016) also list the specific information that must be disclosed in the form of a current report in case of:

- Completion of subscription or sale related to introduction of the issuer's financial instruments to trading in the alternative system,

- Planned or introduced amendment to the articles of association,

- Adopting a resolution on dividend payment,

- Adopting a resolution on an increase of the share capital,

- Not applying by the issuer corporate governance rules mentioned in the document "Best Practices of NewConnect Listed Companies".

Apart from current reports, issuers are required to publish periodic reports, which include both quarterly and annual reports. A list of the minimum information requirements that must be included in these reports has been provided in Table 1. 
Table 1. Minimum mandatory scope of information required to be provided in periodic reports of companies listed on NewConnect

\begin{tabular}{|c|c|}
\hline Type of Report & Minimum information to be provided in the report \\
\hline Quarterly report & $\begin{array}{l}\text { 1) Condensed quarterly financial statements prepared according to the accounting rules } \\
\text { applicable to the issuer; } \\
\text { 2) Information on the rules applied to the preparation of the report, including } \\
\text { information on changes to the applied accounting policy; } \\
\text { 3) Brief description of the most important achievements or failures of the issuer during } \\
\text { the period of the report as well as a description of the most important factors and } \\
\text { events, in particular atypical ones, which impact the achieved results; } \\
\text { 4) If the issuer has published forecasts of financial results - a position on the } \\
\text { probability of achievement of the published forecasts of results for the year in the light } \\
\text { of the results presented in the quarterly report; } \\
\text { 5) If the information document of the issuer contained the general description of planned } \\
\text { activities and investments of the issuer following the introduction of the issuer's } \\
\text { instruments to the alternative trading system - a description of the status of } \\
\text { implementation of activities and investments of the issuer and the timetable of their } \\
\text { implementation; } \\
\text { 6) If the issuer took initiatives to develop its activities aimed to implement innovative } \\
\text { solutions at the enterprise during the period of the report - information on such } \\
\text { activities; } \\
\text { 7) Description of the organisation of the group indicating consolidated entities; } \\
\text { 8) If the issuer holds a group and does not prepare consolidated financial statements - } \\
\text { reasons why such statements are not prepared; } \\
\text { 9) Issuer's shareholding structure including specification of shareholders holding at } \\
\text { least } 5 \% \text { of votes at the general meeting at the date of the report; } \\
\text { 10) Information on the number of persons employed by the issuer. }\end{array}$ \\
\hline Annual report & $\begin{array}{l}\text { 1) Letter of the issuer's management board or managing person with a brief description } \\
\text { of the most important achievements or failures of the issuer during the financial year, } \\
\text { and the prospects for development of the issuer's activities for the next financial year, } \\
\text { and addressees of the annual report; } \\
\text { 2) Selected financial information containing basic items of the annual financial } \\
\text { statements (converted into euros); } \\
\text { 3) Audited annual financial statements; } \\
\text { 4) Report on the issuer's activities; } \\
\text { 5) The issuer's management board's or managing person's declaration that, according } \\
\text { to their best knowledge, annual financial statements and comparable data were } \\
\text { prepared in accordance with regulations applicable to the issuer or internationally } \\
\text { accepted standards and that they present a true and fair view of the issuer's property } \\
\text { and financial situation and its financial result and that the report on the issuer's } \\
\text { activities presents a fair view of the issuer's situation, including a description of basic } \\
\text { exposures and risks; } \\
\text { 6) The issuer's management board's or managing person's declaration that the entity } \\
\text { authorised to audit financial statements which audited annual financial statements was } \\
\text { selected in accordance with legal regulations; } \\
\text { 7) Opinion and report on the audit of the annual financial statements of an entity } \\
\text { authorised to audit financial statements; } \\
\text { - Information about the issuer's application of corporate governance rules, mentioned } \\
\text { in the document "Best Practices of NewConnect Listed Companies". }\end{array}$ \\
\hline
\end{tabular}

Source: Based on the Current and Periodical Information in the Alternative Trading System on the NewConnect Market, 2016.

Consolidated quarterly and annual reports shall contain analogical information concerning the issuer's group. The issuer that is a holding entity is not required to provide a separate quarterly report if the consolidated quarterly report contains adequate information concerning the issuer (Current and Periodical Information in the Alternative Trading System on the NewConnect Market, 2016). 
The quarterly report shall be provided not later than within 45 days of the end of the quarter of the financial year it concerns. The annual report shall be provided not later than within five months after the balance sheet date of the annual financial statements and not later than the day for which the ordinary general meeting of the issuer is convened to approve the annual financial statements presented in the annual report (Current and Periodical Information in the Alternative Trading System on the NewConnect Market, 2016).

The issuer shall prepare financial statements and comparable data in accordance with regulations applicable to the issuer. An issuer based outside the Republic of Poland may prepare financial statements and comparable data in accordance with internationally accepted standards. In line with the Alternative Trading System Rules (2016), Internationally accepted standards are understood as:

a) For issuers or underlying security issuers based in the European Economic Area states: International Accounting Standards, International Financial Reporting Standards and the related interpretations published in the form of the European Commission's regulations.

b) For issuers or underlying security issuers based in non-European Economic Area states: accounting standards required under regulations of third countries which were determined to be equivalent to IAS ${ }^{1}$ or accepted accounting standards ${ }^{2}$.

c) For other standards and for issuers or underlying security issuers based in non-European Economic Area states: International Accounting Standards, International Financial Reporting Standards and the related interpretations published in the form of the European Commission's regulations or International Accounting Standards, International Financial Reporting Standards and the related interpretations issued or adopted by the International Accounting Standards Board.

\section{Breaches of reporting regulations on NewConnect}

The subject of interest on the next stage of research were the irregularities that relate to the fulfilment by listed NewConnect companies of the reporting rules specified in the regulations. The author's earlier research showed that breaches of information requirements are one of the most frequently encountered violations of the rules (Klimczak, 2015).

Among all the breaches of the rules, the following appear:

- Provision of misleading and factually inaccurate information in the information document prepared in connection with the company being listed on the alternative trading system,

- Failing to publish the quarterly report according to the procedure and conditions applicable in the alternative trading systems,

- Failing to make public significant information,

- Failing to publish the opinion on the audit of the financial statement according to the procedure and conditions applicable in the alternative trading systems,

- No agreement for the facilitation of the Market Maker function,

\footnotetext{
${ }^{1}$ According to the mechanism referred to in Article 3 of Commission Regulation (EC) No. 1569/2007 of 21 December 2007 establishing a mechanism for the determination of equivalence of accounting standards applied by third country issuers of securities pursuant to Directives 2003/71/EC and 2004/109/EC of the European Parliament and of the Council (Official Journal of the European Union L 340 of 22.12.2007, p. 66).

${ }^{2}$ Referred to in Article 4 of Commission Regulation (EC) No. 1569/2007 of 21 December 2007 and in Commission decisions issued pursuant to Article 23(4) of Directive 2004/109/EC of the European Parliament and of the Council of 15 December 2004 on the harmonisation of transparency requirements in relation to information about issuers whose securities are admitted to trading on a regulated market and amending Directive 2001/34/EC (Official Journal of the European Union L 390 of 31.12.2004, p. 38, as amended).
} 
- No agreement with the Authorised Adviser during the term required by the Rules.

For the purpose of the research, a list of all the sanctions that were imposed on issuers by the Market Organiser in the years 2009-2015 (List of sanctions imposed by the ATS Organiser on NewConnect issuers linked to the non-compliance with ATS Rules, 2016) was prepared and classified into sanctions resulting from breaches of information duties and sanctions resulting from other infringements of the Rules. This formed the basis for ascertaining the extent of breaches of information duties in all contraventions of the rules. The results of this analysis have been presented in Table 2 .

Table 2. Breaches of the Alternative Trading System Rules in the years 2009-2015

\begin{tabular}{|l|l|l|l|}
\hline Year & $\begin{array}{l}\text { Contraventions of } \\
\text { information requirements; }\end{array}$ & $\begin{array}{l}\text { Other contraventions of the } \\
\text { rules }\end{array}$ & Total \\
\hline 2009 & 1 & 0 & 1 \\
\hline 2010 & 14 & 0 & 14 \\
\hline 2011 & 3 & 0 & 3 \\
\hline 2012 & 47 & 5 & 52 \\
\hline 2013 & 142 & 13 & 155 \\
\hline 2014 & 136 & 19 & 155 \\
\hline 2015 & 179 & 29 & 208 \\
\hline Total & 522 & 66 & 588 \\
\hline
\end{tabular}

Source: Own elaboration on the basis of the List of sanctions imposed by the ATS Organiser on NewConnect issuers linked to the non-compliance with ATS Rules, 2016.

As seen from the above report, information duty violations constitute the main type of infringement of the Alternative Trading System Rules. In the years 2009-2015, they corresponded to $100,100,100,90,92,88$ and 86 percent respectively of all contraventions, and 89 percent of violations in the entire analysed period.

The next step of the study involved verifying in which kind of reports the Alternative Trading System Rules were contravened. The basis for drawing any conclusions similarly to the previous step in the research was the list of sanctions imposed on by the Market Organiser (List of sanctions imposed by the ATS Organiser on NewConnect issuers linked to the noncompliance with ATS Rules, 2016). The results of this analysis have been presented in Table 3.

Table 3. Contraventions of information requirements on the NewConnect market in the years 2009-2015

\begin{tabular}{|l|l|l|l|l|l|}
\hline Year & $\begin{array}{l}\text { Contraventions } \\
\text { relating to } \\
\text { annual reports }\end{array}$ & $\begin{array}{l}\text { Contraventions } \\
\text { relating to } \\
\text { quarterly reports }\end{array}$ & $\begin{array}{l}\text { Contraventions } \\
\text { relating to } \\
\text { annual and } \\
\text { quarterly } \\
\text { reports }\end{array}$ & $\begin{array}{l}\text { Other contraventions } \\
\text { of information } \\
\text { requirements }\end{array}$ & Total \\
\hline 2009 & - & & 1 & 1 & 1 \\
\hline 2010 & 12 & - & 1 & 3 & 14 \\
\hline 2011 & - & - & - & 3 & 3 \\
\hline 2012 & 32 & 12 & & 8 & 47 \\
\hline 2013 & 69 & 65 & 29 & 10 & 142 \\
\hline 2014 & 35 & 62 & 19 & 25 & 136 \\
\hline 2015 & 59 & 76 & 49 & 51 & 179 \\
\hline Total & 207 & 215 & & 522 \\
\hline
\end{tabular}

Source: Own elaboration on the basis of the List of sanctions imposed by the ATS Organiser on NewConnect issuers linked to the non-compliance with ATS Rules, 2016.

It follows from the above list that the highest number of irregularities appears in periodic reports - in the entire analysed period, violations concerning these reports accounted for 90 percent of all the information duty contraventions. 
Further on in the study, attempts were made to identify the most recurring specific types of irregularities in periodic and current reports. To this end, firstly the content of selected resolutions of the Exchange Management Board were analysed where the Market Organiser presents the grounds for the imposition of specific sanctions on relevant companies (Resolutions of the WSE Management Board, 2010; 2012; 2013; 2014; 2015). Furthermore, information conveyed directly by the Alternative System Organiser during presentations, seminars and meetings with market participants was also used (Góral, 2010; Góral, 2013; Góral, 2014; Skłodowska-Balcerek, 2010; Urbanowicz, 2010; Baranowicz, 2012; Rules Governing Current Reporting, 2012). An additional source of information was the opinions of capital market analysts and observers (Świerkowska, 2014; Świerkowska, 2014b; Białowąs, 2013a; Białowąs, 2013b).

The analysis showed that the most frequent irregularities concerning current reports were:

- No report submitted;

- Releasing a periodic report as a current report;

- Exceeding the admissible publication deadlines;

- Inconsistencies with the actual status (through the fault or through no fault of the Issuer);

- Publication of reports on insignificant contracts;

- Non-disclosure of important facts concerning significant contracts (failure to specify the financial terms, failure to provide the party to the agreement, absence of valid information from the point of view of the general terms and conditions of the agreement, failure to furnish information on the reasons for classifying a relevant agreement as significant);

- No reference made to external information regarding the company;

- No reference to sudden exchange rate changes;

- No reference to the reservations of expert auditors;

- No information available on the set issue price for new shares.

Whereas, in relation to quarterly reports, the most commonly repeated errors include:

- Late report publication;

- Irregularities in conveying current and periodical information via the Electronic Information Base (e.g., incorrect designations of reports, missing or incorrect specification of whether or not a given report is a separate or consolidated report);

- Incomplete content of the report in relation to the financial data (lack of required information, e.g., concerning depreciation and amortisation);

- Gaps in non-financial data (no reference to previously published forecasts, perfunctory or obsolete commentary, lack of information on the capital group or reasons for failure to consolidate);

- Clerical mistakes (discrepancies between subsequent quarterly reports and between quarterly figures and incremental year-to-date data presented);

- Poor visual presentation of the report (e.g., inconsistent formatting, illegible attachments).

The most commonly recurring irregularities in annual reports include:

- Late report publication;

- Incomplete report (e.g., lacking selected data converted into euro, absence of any comments, missing report on the audit of the financial statements by the expert auditor, no notes to the financial statements);

- Insufficient level of data comparability;

- Illegible presentation of data;

- No reference made to the application of corporate governance principles. 


\section{Regulatory consequences of a breach of information duties}

The last stage of the research involved finding the answer to the question of what regulatory consequences do companies most commonly expose themselves to in respect of the irregularities in making mandatory information available.

If the issuer fails to comply with the rules or regulations applicable in the alternative trading systems, the NewConnect Organiser has a catalogue of procedural penalties under the Alternative Trading System Rules (2016) at his disposal. He may - depending on the degree and scope of the occurring infringement or violation - reprimand the issuer and/or impose a fine on him amounting to up to PLN 50,000. If the issuer fails to undertake the punishment and continues to remain non-compliant with the provisions, they face the following consequences:

- Fine (where this fine combined with earlier fine imposed on the issuer cannot exceed PLN $50,000)$;

- Suspension of trading in the financial instruments of the issuer in the alternative trading system;

- Delisting of the issuer's financial instruments from the alternative trading system.

The following table summarises the types of sanctions imposed on companies by the NewConnect Organiser for breaches of information obligations in 2009-2015.

Table 4. Types of sanctions imposed for breach of duties on NewConnect (2009-2015)

\begin{tabular}{|c|c|c|c|c|c|c|}
\hline Type of sanction $\quad$ Year & $\begin{array}{l}2009- \\
2011\end{array}$ & 2012 & 2013 & 2014 & 2015 & Total \\
\hline Suspension of trading in shares & 2 & 25 & 79 & 68 & 102 & 276 \\
\hline Exclusion of shares from trading & 1 & 3 & 3 & - & - & 7 \\
\hline $\begin{array}{l}\text { Trading suspension in company shares and } \\
\text { conditional exclusion from trading }\end{array}$ & - & - & - & 11 & 22 & 33 \\
\hline $\begin{array}{l}\text { Trading suspension in company shares and } \\
\text { exclusion from trading }\end{array}$ & - & - & - & 7 & - & 7 \\
\hline Pecuniary penalty & & 14 & 25 & 17 & 33 & 89 \\
\hline Written warning of the company & 1 & 5 & 35 & 29 & 17 & 99 \\
\hline $\begin{array}{l}\text { Written warning and conditional trading } \\
\text { suspension in shares of the company }\end{array}$ & - & - & - & 4 & - & 4 \\
\hline $\begin{array}{l}\text { Written warning and trading suspension in shares } \\
\text { of the company }\end{array}$ & 1 & - & - & - & - & 1 \\
\hline $\begin{array}{l}\text { Written warning and recommendation for other } \\
\text { action to be taken }\end{array}$ & 1 & - & - & - & 5 & 6 \\
\hline Total & 1 & 47 & 142 & 136 & 179 & 522 \\
\hline
\end{tabular}

Source: Own elaboration on the basis of the List of sanctions imposed by the ATS Organiser on NewConnect issuers (2016).

In the analysed period, the Exchange Management Board imposed a total 522 penalties for breaches of information obligations. As seen from the table above, the most commonly imposed penalties were suspension from trading in shares. Throughout the period considered, this penalty constituted 53\% of all the penalties imposed for breach of information duties. The second and third most commonly imposed type of penalty was a warning or a pecuniary penalty, which came to $19 \%$ and $17 \%$, respectively, of all the penalties.

\section{Conclusions}

Based on the conducted analysis, the following final conclusions can be made about the scope and principles of regulatory reporting by companies listed on NewConnect and the types of irregularities connected with the companies meeting information duties. 
Firstly, companies listed on NewConnect are required to prepare current and periodic reports while the Alternative Trading System Rules set out in detail the minimum information requirements applicable to these reports as well as the manner and deadlines for their publication.

Secondly, irregularities in the field of reporting constitute the vast majority of contraventions of NewConnect Rules.

Thirdly, the number of sanctions imposed by the Market Organiser on issuers in connection with non-compliance with information duties steadily increases.

Fourthly, among all the mandatory reports, companies listed on NewConnect experience most problems in filing periodic reports, amongst which the greatest number of irregularities were found in quarterly reports.

Fifthly, the reporting irregularities found concern both its substantive layer and its technical and organisational layer. Thus, not only are there cases where certain essential information is omitted from the reports but also the late publication of reports and some purely technical shortcomings (e.g., presentation of attachments in incorrect format or illegible - due to poor quality - data).

Finally, it should also be noted that companies listed on NewConnect have recently been faced with new challenges. As of 3 July 2016, issuers of securities listed on the alternative trading system are required to comply with the Market Abuse Regulation (Regulation No. 596/2014 of the European Parliament and of the Council of 16 April 2014 on market abuse). Since this time, the publication of a part of the obligatory information takes place not pursuant to the Alternative Trading System Rules but directly on the basis of the relevant provisions of the aforementioned Regulation. Issuers are required to identify circumstances and events in terms of their compliance with the elements essential to the definition of inside information and to make them public in the manner foreseen under the Regulation. Unfortunately, based on preliminary information conveyed by the NewConnect Organiser, many irregularities in this scope have been found in the reports published by issuers after the entry into force of the new provisions. This matter will be examined by the author in further research.

\section{References}

Alternative Trading System Rules (2016), Resolution No. 147/2007 of the WSE Management Board, including amendments (text according to legal condition at 8 August 2016).

Available on line at www.newconnect.pl (10.08.2016)

Baranowicz K. (2012). Sprawozdawczość okresowa spótek z NewConnect-raporty roczne, [Periodic reporting of companies listed on NewConnect - annual reports]. Presentation given on 29 May 2012 at seminar "Information obligations of companies listed on NewConnect". Electronic version available on-line at www.newconnect.pl (10.09.2016)

Białek-Jaworska A., Drązikowska K. (2015). Polityka rachunkowości spółek notowanych na Newconnect [Accounting Policy Used by The Newconnect Listed Companies], Research Papers of Wroclaw University of Economics No. 390.

Białowąs P. (2013a). Wyzwania w procesie raportowania finansowego na rynku NewConnect [Challenges in the financial reporting process on the NewConnect market] (1), "eBiuletyn NewConnect", 4/2013.

Available on-line at www.newconnect.pl (10.09.2016)

Białowąs P. (2013b). Wyzwania w procesie raportowania finansowego na rynku NewConnect [Challenges in the financial reporting process on the NewConnect market] (2), "eBiuletyn 
NewConnect", 5/2013.

Available on-line at www.newconnect.pl (10.09.2016)

Current and Periodical Information in the Alternative Trading System on the NewConnect Market (2016). Exhibit 3 to the Alternative Trading System Rules (text according to legal condition at 8 August 2016).

Available on-line at www.newconnect.pl (10.08.2016)

Dyczkowska J. (2015). Ujawnianie informacji strategicznych w raportach rocznych spółek notowanych na rynkach alternatywnych w Londynie i w Warszawie [Disclosure of Strategic Information In Annual Reports Of Companies Listed At The Alternative Investment Markets In London And Warsaw], Research Papers of Wroclaw University of Economics No. 389.

Góral A. (2010). Raporty kwartalne w regulaminie Alternatywnego Systemu Obrotu.

Najczęstsze błędy [Quarterly Reports in the Alternative Trading System Rules. Most Common Errors], Presentation given on 14.09.2010 at a seminar on the fulfilment of information requirements by companies listed on the NewConnect market, organised by the Issuers Department of the Warsaw Stock Exchange.

Electronic version available on-line at www.newconnect.pl (10.09.2016)

Góral A. (2013). Nowe wyzwania w procesie raportowania finansowego na rynku NewConnect, [New Challenges in the Financial Reporting Process on NewConnect], Presentation given on 23 January 2013 at the conference "Information Duties in the Financial Reporting Process on the NewConnect Market", electronic version available on-line at http://www.xbrl-pl.org/ (10.09.2016)

Góral A. (2014). Sprawozdawczość bieżąca w praktyce - największe trudności, najczęstsze błędy [Current Reports in Practice - The Greatest Difficulties and Most Common Errors], Presentation given on 14 June 2014 at a seminar on "NewConnect - One Year After the Reform".

Electronic version available on-line at www.newconnect.pl (10.09.2016)

Klimczak K. (2015). Naruszenia obowiązków informacyjnych przez spółki notowane na NewConnect [Violations of information obligations of companies listed on NewConnect]. In: Współczesne uwarunkowania sprawozdawczości i rewizji finansowej, Krasodomska J., Świetla K. (eds), Fundacja Uniwersytetu Ekonomicznego w Krakowie, Krakow 2015, pp. 227-239.

NewConnect Annual Market Statistics. Available on line at www.newconnect.pl (30.09.2016)

Regulation No. 596/2014 of the European Parliament and of The Council of 16 April 2014 on market abuse (market abuse regulation) and repealing Directive 2003/6/EC of the European Parliament and of the Council and Commission Directives 2003/124/EC, 2003/125/EC and 2004/72/EC

Resolutions of the WSE Management Board: 696/2010, 700/2010, 701/2010, 702/2010, 703/2010, 704/2010, 705/2010, 706/2010, 707/2010, 708/2010, 709/2010, 710/2010, 711/2010 of 20.07.2010; 458/2012 of 17.05.2012; 649/2012, 651/2012, 655/2012, 656/2012, 666/2012, $667 / 2012$ of 4.07 .2012 ; 524/2013 of 17.05 .2013 ; 573/2013, 574/2013, 575/2013, 576/2013, $577 / 2013$ of $29.05 .2013 ; 739 / 2013$ of 2.07 . $2013 ; 181 / 2014$ of $17.02 .2014 ; 295 / 2014,296 / 2014$, $297 / 2014,298 / 2014$ of $17.03 .2014 ; 1289 / 2014$ of $17.11 .2014 ; 1166 / 2015$ of 17.11 .2015 ; $1113 / 2015$ of $3.11 .2015 ; 1113 / 2015$ of $3.11 .2015 ; 1111 / 2015$ of $3.11 .2015 ; 1079 / 2015$ of 23.10.2015; 928/2015 of 15.09 .2015 ; 900/2015 of 4.09 .2015 ; 769/2015 of 29.07.2015; $629 / 2015 ; 474 / 2015$ of $18.05 .2015 ; 159 / 2015$ of 17.02 .2015 Available on-line at www.newconnect.pl (10.08.2016)

Skłodowska-Balcerek M. (2010). Raporty roczne spółek z rynku NewConnect. Najczęstsze 
błędy [Quarterly Reports in the Alternative Trading System Rules. Most Common Errors], Presentation given on 14.09.2010 at a seminar on the fulfilment of information requirements by companies listed on the NewConnect market, organised by the WSE Issuers Department. Electronic version available on-line at www.neect.pl (10.09.2016)

Świerkowska A. (2014a). Jakość raportów spółek z rynku NewConnect - m Raporty kwartalne [Reporting Quality of Companies Listed on NewConnect - Quarterly Reports], "eBiuletyn NewConnect", 16/2014.

Available on-line at www.newconnect.pl (10.09.2016)

Świerkowska A. (2014b). Jakość raportów spółek z rynku NewConnect - Raporty kwartalne [Reporting Quality of Companies Listed on NewConnect - Quarterly Reports], "eBiuletyn NewConnect", 17/2014.

Available on-line at www.newconnect.pl (10.09.2016)

Góral A. (2010). Raporty kwartalne w regulaminie Alternatywnego Systemu Obrotu.

Wykonywanie obowiązków informacyjnych przez spółki. Najczęstsze błędy [Quarterly Reports in the Alternative Trading System Rules. Most Common Errors], presentation given on 14.09.2010 at a seminar on the fulfilment of information requirements by companies listed on the NewConnect market, organised by the Issuers Department at the WSE.

Electronic version available on-line at www.newconnect.pl (10.09.2016)

Zasady sporządzania raportów bieżących [Rules Governing Current Reporting] (2012), presentation given on 29 May 2012 at the seminar "Information Duties of Companies listed on NewConnect" by the WSE Issuers Department.

Electronic version available on-line at www.newconnect.pl (10.09.2016)

Zestawienie sankcji nałożonych przez Organizatora ASO na emitentów NewConnect, w związku z nieprzestrzeganiem przepisów Regulaminu ASO [List of Sanctions Imposed by the ATS Organiser on NewConnect Issuers in connection with non-compliance with ATS Rules] (2016).

Available on-line at www.newconnect.pl (10.09.2016)

Zawadzki A. (2014). Standardy sprawozdawczości w zakresie środków unijnych w polskich spółkach notowanych na Newconnect [Standards of EU Funds Reporting. In: Polish Companies Listed on The Newconnect Market], Research Papers of Wroclaw University of Economics No. 329 